\title{
The Great Extravaganza
}

\author{
HUGH McLAUGHLIN, Lewvan, Sask.
}

Here on the plains we have been basking in the sunshine and mild weather of a lovely fall. But. the spring and summer were quite the opposite and in retrospect we can look back on the unusal.

Spring started out dry. There was barely enough snow to bring down a flood in the creek. Field work started early and even low spots on the land, usually flooded, were seeded right through. The ducks by-passed us to a certain extent and were not nesting in their usual numbers. Then came the unseasonable snow and frost that took such a toll of early nests.

Work had scarcely been resumed on $t$ he land when rain, again, drenched the countryside. I have sometimes visioned a living flowing stream and thought how poor in comparison a mere creek that subsided after the spring runoff. The next several weeks changed some of those ideas. Four inches of rain fell one night and thereafter an inch or two poured down on us whenever the extensive pools formed showed the least sign of retreating. And the water flowed: little rivulets into ditches - little ditches in channels and thence into great moving flats of water. When I pumped out my basement the water did not evaporate it merely flowed over the saturated earth - joined its fellows in the roadside ditch and set out for Hudson Bay, via Souris Creek. The other end of this magis fluid, perhaps, lapped on the shores of England and our little ponds were joined to the brotherhood of other waters that encircled the earth. Not clear glistening streams were these, but cloudy water - and always going downstream were floating snails.

You may wonder why I should recount all this, but in the face of what amounted to futility in regard to farming (Tillage seeding implements were not recovered from muddy flats till sometime in July) I thought I would report its effects on the creatures of nature - bewildering circumstances to them also They - creatures with small rea-

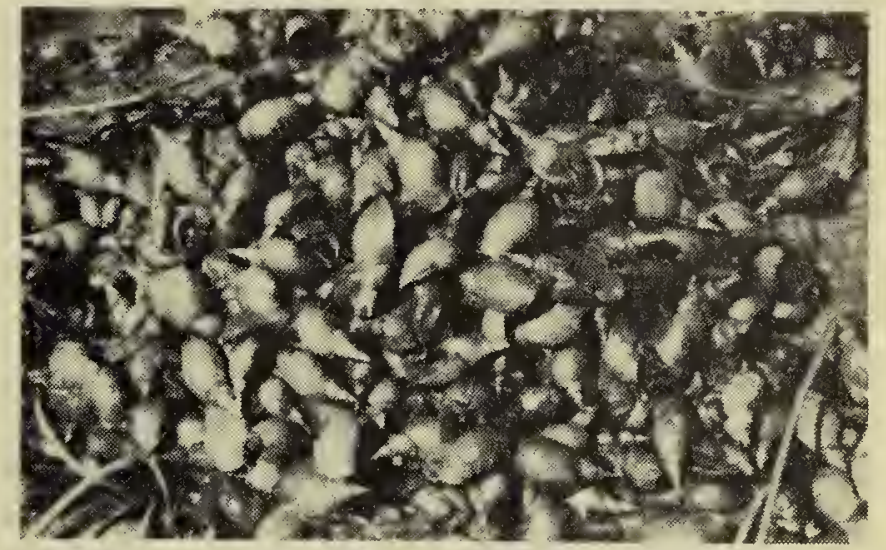

Photo by Hugh McLaughlin

soning - but supplied with divine guidance - how would they react?

There was a great return of ducks to the area, both Green and Bluewinged Teal being especially abundant. The Red-winged Blackbirds, whose nests and eggs had been saturated in the buck-brush along the creek, moved over a few feet, and over the water that still surged, built another nest - but higher. Higher seemed to be the theme and the duck nests were on ridges between fields or knolls. There were quite on influx of Bittern and Blackcrowned Heron. Every low-lying ditch became a march with cat-tails. The Bittern could be heard in the evening right in the village, while the Muskrat and ducks made themselves at home in every roadside ditch. But most surprising was a quite pronounced number of Great Blue Herons. They must have been disturbed out of their usual colonies by the weather. I am quite sure that they never nested here. Possibly their trip to breeding grounds this year was a futile one.

Whatever the cause, these birds not normally seen here, except as an occasional fall migrant, graced nearly a dozen localities - big ponds or pools along the creek. One in particular claimed a pond north of town and could be seen all summer. It would rise at every passing car but always returned. There was an abundance of food. As flood waters retreated a great crop of minnows, snails and other aquatic life would find themselves trapped in diminishing pools where these stilted epicures could feast in leisure until the 
sun's rays flicked out the last drop of water.

I thought to add to the variety of local pond life by bringing home three or four Leopard Frogs from a trip, and turning them loose. But all at once it seemed as if these agile ones were in every pool and dugout. Mother Nature had beaten me with her own bounteous hand. I had never seen one locally before.

A couple of years ago I brought home and planted a few coreospsis plants as they seemed to be quite a rarity in recent years - but again I had not counted on Nature. It was thus:

I was one day stricken to notice a yellow tinge come over several acres of ground that had emerged from the water and at once thought it must be a great crop of Sow Thistles, and wondered how to get at it. It was too muddy to get near to spray or to destroy by cultivation. However I waded out to investigate. To my surprise it turned out to be acres of Coreopsis. A million little eyes of yellow and maroon. all turned by the west wind to face me. I had never seen these plants there before.

In other cultivating fields - long since civilized to wheat and mustard the wild marsh grass sprang up to remind us that we are not so far removed from the primitive. These seeds just lay hidden unknown until their day came.

The waters of the creek flowed on through June and July - not muddy now - instead a luscious growth of green algae - masses in the quiet waters, and long waving streamers where the water spread over a small dam. Such a goodly flowing stream looked as if it should contain fish. Such was not the case. Instead, feeding on their submerged pasture, grazing like contented sheep on a hillside - clustered in places like fat grapes - were Great Pond Snails helping to clean the mossy channel.

Finally in August thin places showed in the stream. It was impossible to get across to do field work or to cut hay. Trapped by weeds in the shallow water were about four inches of snails - in places 6 to 8 feet wide. There was no choice but to barge right through them. Their gritty shells must have provided good traction as we "no got stuck" once. It would have been quite easy to have filled the truck with live snails.

Now the great extravaganza of that season has passed - gone the Herons, Bitterns and Mosquitoes, and only can I submit to you "snaps of Snails".

\section{Carp (Cyprinus, Carpio) Established in Province}

A. H. MacDonald, Dir. of Fisheries,

Dept. of Natural Resources, P.A.

The first definite proof that Carp (Cyprinus Carpio) had become established in Saskatchewan was produced this fall with the discovery of numerous six-inch Carp in ditches and sloughs adjacent to the Assiniboine River near Kamsack. During the spring the banks of the river at this point were flooded and adult Carp spawned in the ditches and fields.

Although considered an important food fish in many parts of Europe and Asia, Carp are generally considered an undesirable species all over America. Their high productivity and ability to withstand environmental limitations have enabled the species to become established in most parts of the continent, often at the expense of desirable native species.

The carp is omnivorous in its feeding habits, but the principal food is insect larvae, crustaceans and other bottom organisms. Its habit of rooting amongst aquatic plants keeps the water constantly muddy and, aside from destroying aquatic plants, the muddy water is detrimental to other species. It can survive for days in a closed container and may be transported great distances and used as bait. It is illegal to carry live bait from one lake to another in Saskatchewan, and anglers are warned of the danger of extending the range of this undesirable species.

Carp were introduced into the United States from Germany in 1872 by J. A. Poppe and planted in California, and today it is established in practically every State. They were unknown in Manitoba until 1938, and are now plentiful in the Red and Winnipeg Rivers, and more recently in the Assiniboine. 